\title{
PELEPASAN ION NIKEL DAN KROMIUM BRAKET STAINLESS STEEL YANG DIRENDAM DALAM MINUMAN BERKARBONASI
}

\author{
${ }^{1}$ Indri Sumule \\ ${ }^{2}$ P. S. Anindita \\ ${ }^{2}$ Olivia A.Waworuntu \\ ${ }^{1}$ Kandidat Skripsi Program Studi Kedokteran Gigi Fakultas Kedokteran \\ ${ }^{2}$ Bagian Mikrobiologi Fakultas Kedokteran \\ Universitas Sam Ratulangi Manado \\ Email: indrisumule@yahoo.com
}

\begin{abstract}
Stainless steel bracket is one of metal components which is used in oral cavity. Metal substance that is implied can be corroded if it is placed in corrosive media, like carbonated drink. The corrosion can be seen from the release of $\mathrm{Ni}$ and $\mathrm{Cr}$ ions which are harmful for our bodies. This study aimed to obtain the release of $\mathrm{Ni}$ and $\mathrm{Cr}$ from stainless steel bracket after being immersed in carbonated drink. This was an experimental laboratory study with a post test only control group design. Samples were tested with spectrometry uv-visible to determine the release of $\mathrm{Ni}$ and $\mathrm{Cr}$ ions. There were 8 brackets as samples, divided into 2 groups, each of 4 samples. Stainless steel brackets were immersed in non-carbonated drink saliva and carbonated-drink saliva for 312 minutes. The results showed a difference of $\mathrm{Ni}$ and Cr ion release of both groups, but the group of brackets immersed in carbonated drink showed a greater release than the other group. The release of $\mathrm{Ni}$ ions in the control group had an average of $1.556 \mathrm{ppm}$ and in the treatment group of $2.624 \mathrm{ppm}$ meanwhile the release of $\mathrm{Cr}$ ions in the control group had an average of $0.038 \mathrm{ppm}$ and in the treatment group of 0.109 ppm.
\end{abstract}

Keywords: stainless steel bracket, ion $\mathrm{Ni}$ and $\mathrm{Cr}$, carbonated drink

\begin{abstract}
Abstrak: Braket stainless steel merupakan salah satu komponen logam yang digunakan didalam rongga mulut. Bahan logam tersebut dapat mengalami korosi bila berada di media korosif seperti minuman berkarbonasi. Korosi dapat dilihat dari pelepasan ion $\mathrm{Ni}$ dan $\mathrm{Cr}$ yang bersifat merugikan bagi tubuh. Penelitian ini bertujuan untuk mengetahui jumlah pelepasan ion $\mathrm{Ni}$ dan $\mathrm{Cr}$ dari braket stainless steel yang direndam dalam minuman berkarbonasi. Jenis penelitian ini ialah eksperimental laboratorik dengan rancangan post test only control group. Sampel dilakukan uji dengan alat spektrofotometri uv-visible untuk mengetahui pelepasan ion Ni dan Cr. Delapan buah sampel berupa larutan dibagi menjadi dua kelompok masing-masing dengan empat buah sampel. Braket stainless steel direndam dalam saliva tanpa minuman berkarbonasi dan saliva dengan minuman berkarbonasi selama 312 menit. Hasil penelitian menunjukkan terdapat perbedaan pelepasan ion $\mathrm{Ni}$ dan $\mathrm{Cr}$ pada kedua kelompok. Pada kelompok yang direndam dengan minuman berkarbonasi terjadi pelepasan ion $\mathrm{Ni}$ dan $\mathrm{Cr}$ lebih besar dengan rerata pelepasan ion Ni pada kelompok kontrol 1,556 ppm dan pada kelompok perlakuan 2,624 ppm, sedangkan rerata pelepasan ion Cr pada kelompok kontrol 0,038 ppm dan pada kelompok perlakuan 0,109 ppm.
\end{abstract}

Kata kunci: braket stainless steel, ion Ni dan Cr, minuman berkarbonasi 
Kebutuhan akan perawatan ortodonti telah menjadi salah satu perawatan gigi yang penting. Perawatan ortodonti bertujuan memberikan perbaikan estetik dan fungsional pada pasien. Kendala dalam perawatan ortodonti yaitu waktu perawatan yang relatif lama sehingga diperlukan komponen alat yang aman, nyaman dan dapat bertahan dalam jangka waktu yang lama di dalam mulut. ${ }^{1-3}$

Braket ortodonti merupakan salah satu komponen utama dalam perawatan ortodonti cekat yang berfungsi menghantarkan gaya yang diperlukan pada gigi, oleh karena itu braket yang digunakan harus diproduksi dengan akurat, baik dari segi bentuk, tingkat kekuatan maupun tingkat ketahanan korosi serta biokompatibilitas. Umumnya braket ortodonti yang banyak digunakan terbuat dari logam stainless steel yang komposisinya terbuat dari besi (Fe), kromium (Cr) dan nikel (Ni). Braket stainless steel banyak digunakan karena komponen mekanisnya yang lebih baik dibandingkan dengan braket yang terbuat dari plastik ataupun keramik, harganya yang lebih ekonomis dan tahan terhadap korosi. $^{1-4}$

Korosi merupakan hasil proses interaksi antara material logam dengan lingkungan di sekitarnya. Salah satu penyebab proses korosi adalah lingkungan dengan $\mathrm{pH}$ asam. Pada proses korosi braket stainless steel di dalam rongga mulut, terjadi pelepasan ion logam yang dapat masuk ke dalam tubuh serta dapat menimbulkan efek seperti karsinogenik, alergenik, mutagenik dan sitotoksik. Korosi menunjukkan penampakan secara visual ketika terjadi dalam waktu yang lama, tetapi secara mikro dalam waktu yang tidak begitu lama korosi dapat dideteksi dengan adanya proses oksidasi dan reduksi yang mengakibatkan terlepasnya ion-ion dari unsur yang terkandung.

Sebagian besar alat ortodonti yang terbuat dari stainless steel yang memiliki tingkat ketahanan korosi tinggi mengandung $8-12 \% \mathrm{Ni}$ dan $17-22 \% \mathrm{Cr}$. Pembahasan mengenai $\mathrm{Ni}$ dan $\mathrm{Cr}$ lebih banyak mendapatkan perhatian mengingat banyaknya laporan mengenai potensinya terhadap reaksi alergi, efek toksik dan karsinogenik. Baik Ni maupun $\mathrm{Cr}$ dapat menyebabkan hipersensitivitas pada beberapa orang., ${ }^{2,7}$

Suasana di dalam rongga mulut dapat berubah-ubah baik netral asam maupun basa. Perubahan suasana dalam rongga mulut juga dapat diakibatkan salah satunya dari konsumsi minuman berkarbonasi yang memilki pH asam. Minuman berkarbonasi atau yang biasa disebut soft drink seolah menjadi trend masyarakat modern. Di Amerika setengah dari penduduk negara ini mengkonsumsi minuman tersebut. Di negara maju, hal ini telah lama terjadi dengan rata-rata konsumsi 12 kaleng tiap orang perminggu. Begitupun di Indonesia dimana penduduknya cenderung menganut gaya kebarat-baratan, salah satunya ditandai dengan semakin banyak tempat makan yang menyajikan fast food dimana sebagian besar menggantikan air pendamping makanan dengan minuman berkarbonasi. $^{5,9}$

Dari banyaknya konsumsi minuman berkarbonasi ini, dicurigai dapat menyebabkan korosi stainless steel bagi masyarakat yang melakukan perawatan ortodontik. Hal ini dikarenakan minuman berkarbonasi mengandung karbondioksida yang menghasilkan asam karbonat dimana asam ini merupakan asam lemah. Adanya stainless steel dalam rongga mulut dan suasana asam yang terjadi terus menerus inilah yang dapat memengaruhi komponen logam dari stainless steel tersebut sehingga dapat mempercepat proses korosi. ${ }^{6,10}$

Berdasarkan latar belakang diatas penulis terdorong untuk mengetahui jumlah pelepasan ion $\mathrm{Ni}$ dan $\mathrm{Cr}$ dari braket stainless steel yang direndam dalam minuman berkarbonasi.

\section{METODE PENELITIAN}

Desain penelitian yang digunakan ialah eksperimental laboratorik dengan rancangan post-test only control. Penelitian ini dilakukan di Laboratorium Politeknik Kesehatan Kemenkes Manado. Waktu penelitian dilaksanakan pada bulan Maret- 
September 2015. Sampel penelitian ialah braket stainless steel dengan menggunakan merk x yang direndam dalam 2 kelompok larutan. Besar sampel ditetapkan sesuai dengan rumus sampel data numerik:

$$
\begin{aligned}
& n=2\left[\frac{(\mathrm{Z} \alpha+Z \beta) \mathrm{S}}{(\mathrm{X} 1-\mathrm{X} 2)}\right)^{2} \\
& \mathrm{n}=2\left[\frac{(1,64+0,842) 0,4}{0,5}\right]^{2} \\
& \mathrm{n}=2[1,98]^{2} \\
& \mathrm{n}=7,8 \longrightarrow 8
\end{aligned}
$$

$\mathrm{n}=$ jumlah subjek

$\mathrm{s}=$ simpang baku

$\alpha=$ kesalahan tipe 1

$\beta=$ kesalahan tipe 2

$\mathrm{x}_{1}-\mathrm{X}_{2}=$ perbedaan klinis yang diinginkan (clinical judgment)

Ditetapkan kesalahan tipe I sebesar 5\% dan hipotesis dua arah, sehingga $Z \alpha=1,64$. Kesalahan tipe II ditetapkan sebesar 20\%, sehingga $Z \beta=0,842$. Selisih minimal yang dianggap bermakna yaitu $\left(\mathrm{x}_{1}-\mathrm{x} 2\right)=0,5$, standar deviasi $=0,4$ dengan menggunakan rumus analitik numerik tidak berpasangan, maka jumlah sampel yaitu 8, 4 pada kelompok kontrol dan 4 pada kelompok perlakuan. Pengukuran jumlah pelepasan ion $\mathrm{Ni}$ dan $\mathrm{Cr}$ pada sampel kontrol dan perlakuan menggunakan alat spektrofotometri uv-visible Pelaksanaan penelitian diawali dengan mengelompokkan sampel yang terdiri dari 8 larutan braket stainless steel masing-masing menjadi 2 kelompok yaitu 4 pada kelompok kontrol dan 4 pada kelompok perlakuan. 8 larutan diambil dari 4 set braket stainless steel. 1 set braket stainless steel berisi 10 buah braket rahang atas dan 10 buah braket rahang bawah. 2 set braket stainless steel digunakan sebagai kelompok kontrol dan 2 set braket stainless steel lainnya digunakan sebagai kelompok perlakuan. Pada saat pembagian kelompok kontrol dan perlakuan selesai, selanjutnya dilakukan pengukuran braket stainless steel menggunakan timbangan digital untuk menentukan banyaknya cairan perendaman dengan perbandingan $1 \mathrm{ml}$ larutan setiap $0,2 \mathrm{~g}$ braket. Braket stainless steel yang terdapat pada kelompok kontrol direndam ke dalam larutan saliva buatan dengan $\mathrm{pH}$ 6,8 dan untuk kelompok perlakuan direndam dalam saliva buatan dengan $\mathrm{pH}$ 6,8 yang ditambahkan dengan minuman berkarbonasi yang memiliki $\mathrm{pH}$ asam. Braket stainless steel direndam menggunakan masing-masing tabung durham yang telah diberi label sebagai penanda pada kelompok kontrol dan kelompok perlakuan, kemudian ditutup rapat, selanjutnya dilakukan penyimpanan di inkubator pada temperatur $37^{\circ} \mathrm{C}$ selama 312 menit. Setelah dilakukan perendaman selama 312 menit, braket stainless steel dipisahkan dari larutan pada kelompok kontrol dan kelompok perlakuan kemudian pada larutan kedua kelompok ini dilanjutkan dengan melakukan analisis terhadap lepasan ion logam yang ditentukan, dalam hal ini yaitu ion $\mathrm{Ni}$ dan $\mathrm{Cr}$. Pada saat melakukan analisis, pada kelompok kontrol saliva buatan ditambahkan asam nitrat dan 1\% larutan difenilkarbazida untuk mendeteksi $\mathrm{Cr}$ sedangkan untuk mendeteksi $\mathrm{Ni}$ ditambahkan 1\% larutan dimetilglikosim dan ammonium hidroksida pada larutan. Hal yang sama berlaku pada kelompok perlakuan kecuali ditambahkannya asam nitrat. Selanjutnya digunakan alat spektrofotometri uv-visible untuk mengetahui jumlah pelepasan ion $\mathrm{Ni}$ dan $\mathrm{Cr}$ dalam saliva menggunakan pada kelompok kontrol dan kelompok perlakuan. Data yang telah diperoleh kemudian diolah dalam bentuk tabel dengan program komputerisasi.

\section{HASIL PENELITIAN}

Hasil penelitian menunjukkan bahwa jumlah pelepasan ion Ni pada kelompok perlakuan (minuman berkarbonasi) lebih besar daripada kelompok kontrol (saliva buatan dengan $\mathrm{pH}$ 6,8) dengan selisih nilai yang cukup jauh berbeda pada tiap sampelnya. Nilai rerata pada kelompok kontrol menunjukkan lebih dari 1 ppm dan pada kelompok perlakuan lebih dari 2 ppm. 
Tabel 1. Jumlah pelepasan ion Nikel (Ni) yang terjadi pasca perendaman pada kelompok kontrol dan perlakuan

\begin{tabular}{ccc}
\hline \multirow{2}{*}{ Kelompok } & \multicolumn{2}{c}{ Pelepasan Ion Nikel (Ni) } \\
\cline { 2 - 3 } & $\begin{array}{c}\text { Jumlah } \\
\text { (ppm) }\end{array}$ & $\begin{array}{c}\text { Rerata } \\
\text { (ppm) }\end{array}$ \\
\hline Kontrol & & \\
1 & 1,533 & \\
2 & 2,192 & 1,556 \\
3 & 1,315 & \\
4 & 1,185 & \\
Perlakuan & & \\
1 & 2,623 & \\
2 & 3,004 & 2,624 \\
3 & 2,461 & \\
4 & 2,408 & \\
\hline
\end{tabular}

Berdasarkan pengukuran yang dilakukan terhadap sampel, dapat dilihat rerata pelepasan ion $\mathrm{Cr}$ pada Tabel 2. Hasil menunjukkan bahwa jumlah pelepasan ion Cr pada kelompok perlakuan (minuman berkarbonasi) lebih besar daripada kelompok kontrol (saliva buatan dengan $\mathrm{pH}$ 6,8) dengan nilai rerata kurang dari 1 ppm pada kelompok kontrol dan kelompok perlakuan.

Tabel 2. Jumlah pelepasan ion Kromium (Cr) yang terjadi pasca perendaman pada kelompok kontrol dan perlakuan

\begin{tabular}{ccc}
\hline & \multicolumn{2}{c}{$\begin{array}{c}\text { Pelepasan Ion Kromium } \\
\text { Kelompok }\end{array}$} \\
\cline { 2 - 3 } & $\begin{array}{c}\text { Jumlah } \\
\text { (ppm) }\end{array}$ & $\begin{array}{c}\text { Rerata } \\
\text { (ppm) }\end{array}$ \\
\hline Kontrol & & \\
1 & 0,047 & \\
2 & 0,037 & 0,038 \\
3 & 0,034 & \\
4 & 0,034 & \\
Perlakuan & & \\
1 & 0,118 & \\
2 & 0,102 & 0,109 \\
3 & 0,094 & \\
4 & 0,123 & \\
\hline
\end{tabular}

\section{BAHASAN}

Hasil penelitian menunjukkan bahwa meskipun sampel yang digunakan dari merek yang sama namun jumlah pelepasan yang ditimbulkan oleh pelepasan ion $\mathrm{Ni}$
(Tabel 1) dan Cr (Tabel 2) memiliki jumlah nilai yang bervariasi pada setiap sampelnya. Pada penelitian serupa yang dilakukan Aryani di Balai Besar Laboratorium Kesehatan Jakarta pada bulan Februari tahun 2012, jumlah pelepasan ion $\mathrm{Ni}$ dan $\mathrm{Cr}$ yang diuji pada beberapa merek braket stainless steel yang direndam dalam saliva buatan selama 30 hari juga memiliki nilai jumlah pelepasan yang berbeda pada setiap merek braket yang diuji. Berdasarkan hasil penelitian, diketahui pula bahwa pelepasan ion $\mathrm{Ni}$ lebih banyak dibandingkan dengan ion $\mathrm{Cr}$, hal ini berbanding terbalik dengan hasil penelitian yang dilakukan Aryani dan Kristianingsih dimana braket stainless steel yang direndam dalam saliva dan kawat ortodonti stainless steel yang direndam dalam minuman berkarbonasi menunjukkan pelepasan ion $\mathrm{Cr}$ lebih banyak dikeluarkan dari ion Ni. Hal ini mungkin terjadi karena komposisi dari braket stainless steel yang pencampurannya tidak homogen pada saat proses pembuatannya sehingga dapat menghasilkan nilai pelepasan yang bervariasi meskipun dalam satu merek dan para produsen braket stainless steel yang tidak mematuhi standar batas aman mengenai komposisi logam braket stainless steel. $^{5,11}$

Hasil penelitian juga menunjukan bahwa jumlah pelepasan ion Ni (Tabel 1) dan ion Cr (Tabel 2) pada kelompok perlakuan yang direndam dalam minuman berkarbonasi lebih banyak daripada kelompok yang direndam dalam saliva buatan, dimana kelompok ini dijadikan kontrol. Pada kelompok kontrol tetap terjadi pelepasan ion $\mathrm{Ni}$ dan $\mathrm{Cr}$ akibat pengaruh dalam saliva. Menurut Almeida et al, saliva terdiri dari sebagian besar air, dan sebagian lain adalah komponen organik seperti protein yang berupa enzim dan komponen anorganik seperti bikarbonat, fosfat, natrium, kalium, potassium, klorida dan magnesium. ${ }^{12}$ Komponen anorganik inilah yang berperan sebagai media elektrolit yang dapat memicu reaksi elektrokimia. Reaksi elektrokimia merupakan reaksi yang terjadi pada anoda 
(mengalami oksidasi) dan katoda (mengalami reduksi), dimana ion logam sebagai anoda dan ion $\mathrm{H}^{+}$dari media elektrolit sebagai katoda. Reaksi elektrokimia inilah yang membuat sehingga terjadi pelepasan ion $\mathrm{Ni}$ dan $\mathrm{Cr}$ dari braket ortodontik stainless steel sebagai tanda terjadinya korosi. ${ }^{6,13}$

Pada penelitian yang dilakukan Kuhta et al di India tahun 2009 menyebutkan bahwa terjadi pelepasan ion logam titanium (Ti), kromium (Cr), nikel $(\mathrm{Ni})$, besi $(\mathrm{Fe})$, tembaga $(\mathrm{Cu})$ dan zing $(\mathrm{Zn})$ pada alat ortodontik cekat setelah direndam dalam saliva buatan $\mathrm{pH} 6,75 \pm 0,15$ selama 1,7 , 14, dan 28 hari. Pemeriksaan saliva hasil perendaman pada penelitian tersebut menunjukkan bahwa pelepasan ion logam paling besar terjadi pada 1-7 hari setelah perendaman dan menurun seiring bertambahnya waktu perendaman. Hal inilah yang mungkin terjadi pada braket stainless steel yang meskipun hanya direndam selama 5 jam namun mengeluarkan jumlah pelepasan ion yang cukup besar karena terlepasnya ion $\mathrm{Ni}$ dan Cr pada awal waktu perendaman. ${ }^{14}$

Pada kelompok yang direndam dalam minuman berkarbonasi juga terjadi pelepasan ion $\mathrm{Ni}$ dan $\mathrm{Cr}$ lebih banyak karena adanya penambahan konsentrasi ion $\mathrm{H}^{+}$dari asam karbonat $\left(\mathrm{H}_{2} \mathrm{CO}_{3}\right)$. Asam karbonat dapat meningkatkan potensi terjadinya korosi. Hal ini karena tingginya konsentrasi asam dan semakin banyak ion $\mathrm{H}^{+}$dari asam yang ikut bereaksi dan mengalami reduksi. Akibatnya, semakin banyak pula ion logam yang mengalami oksidasi sehingga mempercepat proses korosi. Karena selama proses korosi braket stainless steel, laju oksidasi sebanding dengan laju reduksi yang ditandai dengan meningkatnya pelepasan ion $\mathrm{Ni}$ dan $\mathrm{Cr}$ dari braket tersebut. ${ }^{5,13}$

\section{SIMPULAN}

Berdasarkan hasil penelitian yang dilakukan pada braket stainless steel yang direndam dalam minuman berkarbonasi dapat disimpulkan bahwa pada kelompok yang direndam dengan minuman berkarbonasi terjadi pelepasan ion $\mathrm{Ni}$ dan Cr lebih besar daripada kelompok kontrol. Rerata pelepasan ion $\mathrm{Ni}$ pada kelompok kontrol 1,556 ppm dan pada kelompok perlakuan 2,624 ppm, sedangkan rerata pelepasan ion $\mathrm{Cr}$ pada kelompok kontrol 0,038 ppm dan pada kelompok perlakuan $0,109 \mathrm{ppm}$.

\section{SARAN}

1. Perlu dilakukan penelitian lebih lanjut untuk melihat jenis korosi braket stainless steel setelah direndam minuman berkarbonasi secara in vivo.

2. Perlu dilakukan penelitian lebih lanjut mengenai efek minuman berkarbonasi pada braket stainless steel pada jangka waktu yang berbeda.

\section{UCAPAN TERIMA KASIH}

Ucapan terima kasih disampaikan pada Prof. Fatimawali, MSi.,Apt, drg. Christy Mintjelungan, Mkes, dan pada semua pihak yang baik secara langsung maupun tidak langsung telah menumbuhkan ide atau gagasan dalam pemikiran penulis.

\section{DAFTAR PUSTAKA}

1. Lin MC, Lin SC, Lee TH, Huang HH. Surface Analysis and Corrosion Resistance of Different Stainless Steel Orthodontic Brackets In Artificial Saliva Angle Orthod 2006; 76:322-29.

2. Oh KT, Choo SU, Kim KM, Kim KN. A Stainless steel Bracket for Orthodontic Application Eur J Orthod 2005;27:237-44.

3. House K, Sernetz F, Dymock D, Sandy J, Ireland A. Corrosion of Orthodontic Appliances-should we care? Am J Orthod Dentofacial Orthop 2008;133:584-92.

4. Souza RM, Menezes LM. Nickel, Chromium and Iron Levels in the Saliva of Patients with Simulated Fixed Orthodontic Appliances. Angle Orthod 2008;78;345-35.

5. Kristianingsih R, Joelijanto R, Praharani D. Analisis Pelepasan Ion $\mathrm{Ni}$ dan $\mathrm{Cr}$ Kawat Ortodontik Stainless Steel yang Direndam dalam Minuman Berkarbonasi [Artikel Ilmiah Hasil 
Penelitian Mahasiswa]. Jember: Fakultas Kedokteran Gigi UNEJ; 2014.

6. Bardal E. Corrosion and Protection. United Stated of America: Springer-Verlag London Limited; 2004. Chapter 1, Introduction; p.14.

7. Kocadereli I, Atac A, Kale S, Ozer D. Salivary Nickel and Chromium in Patients with Fixed Orthodontic Appliances. Angle Orthod 2000;70:431-34.

8. Neama ZT. Nickel and Chromium Ions Levels In Saliva Of Patients With Fixed Orthodontic Appliances. Medical Journal of Babylon. 2014;11(3):558.

9. Prasetya RC. Perbandingan jumlah koloni bakteri saliva pada anak-anak karies dan non karies mengkonsumsi minuman berkarbonasi. Indonesian Jurnal of Dentistry. 2008;15(1):65-70.

10.Tahmassebi JF, Duggal MS, Malik-Kotru G, Curzon ME. Softdrinks and
Dental Health: A review of current literature. J Dent. 2006;24(1):2-11.

11.Aryani I, Siregar E, Krisnawati. Perbandingan tingkat ketahanan korosi beberapa braket stainlees steel ditinjau dari lepasan ion $\mathrm{Cr}$ dan $\mathrm{Ni}$ (Tesis). Jakarta (Indonesia): Bagian Ortodonti Universitas Indonesia; 2008.

12. Almeida PDV, Gregio AMT, Lima AAS, Azevedo LR. Saliva Composition and Function: A Comprehensive Review. The Journal of Contemporary Dental Practice. 2005; 9(3):1-11.

13.Fontana MG. Corrosion Engineering (3rd Edition). Singapore: McGraw-Hill Book Company, 1987.

14.Kuhta M, Pavlin D, Slaj M, Varga S, Varga ML. Type of Archwire and level of Acidity: Effects on the Release of Metal ions from Orthodontic Appliance. Angle Orthod. 2009;79(1):102-10. 